\title{
Crystal Structure of $(d l)$-Corynoloxine
}

\author{
Miyoko KAMIGauCHI,* Yuko NodA,* Kinuko IwaSA, ${ }^{*}$ Yasuko IN, ${ }^{* *}$ and Toshimasa ISHIDA** \\ *Department of Physical Chemistry, Kobe Pharmaceutical University, Motoyamakita, Higashinada, \\ Kobe 658-8558, Japan \\ **Department of Physical Chemistry, Osaka University of Pharmaceutical Sciences, Nasahara, \\ Takatsuki 569-1094, Japan
}

\begin{abstract}
The crystal structure of the racemic alkaloid $(d l)$-corynoloxine (1), 5b,6,7,12b,13,14-hexahydro-5b,13-dimethyl-6,14epoxy-1,3-dioxolo[4,5-i][1,3]dioxolo[4,5]benzo[1,2-c]phenanthridine, is reported here. The crystal is orthorhombic, space group Pbca with $a=20.375(3) \AA, b=41.499(3) \AA, c=8.139(3) \AA$, and $Z=16$. The crystal contains two crystallographically independent molecules. These two molecules take essentially the same conformation.
\end{abstract}

(Received September 8, 2008; Accepted November 17, 2008; Published on web January 7, 2009)

$(d l)$-Corynoloxine $(\mathbf{1})$ is an hexahydrobenzo $[c]$ phenanthridinetype alkaloid uniquely isolated as a racemate from Corydalis incisa (Papaveraceae). ${ }^{1}$ The structure of 1 (Fig. 1) has been decided by spectroscopic and chemical methods. ${ }^{2}(d l)-\mathbf{1}$ is biosynthesized from $(d l)$-Corynoline (2), which is the main alkaloid of $C$. incisa. Previously, we reported on the correlation of the structure and the adhesion inhibitory effect on corynoline (2). ${ }^{3}$

It was found that $(d l)-\mathbf{1}$ showed a comparatively advantageous inhibitory effect for adhesion control between human umbilical vein cultured endothelial cell (HUVEC) and human polymorphonuclear leukocyte (PMNCs). ${ }^{4}$ To understand the cell-adhesion inhibitory effect of $\mathbf{1}$ for its receptor protein (ICAM-1, etc.), it is important to know the detailed structure of $(d l)-\mathbf{1}$, and thus it was investigated by $\mathrm{X}$-ray structure analysis.

$(d l)-\mathbf{1}$ was obtained by the oxidation of $(d l)-\mathbf{2}$. $(d l)-\mathbf{2}(100 \mathrm{mg})$ was dissolved in a mixture of $\mathrm{AcOH}(5 \%)$ and $\mathrm{Hg}_{2}(\mathrm{OAc})_{2}(210$ $\mathrm{mg}$ ) and stirred at $98^{\circ} \mathrm{C}$. After $4 \mathrm{~h}$, the reaction mixture was adjusted to $\mathrm{pH} 10$ with $\mathrm{NH}_{4} \mathrm{OH}(28 \%)$ solution and extracted with ether $(2 \times 200 \mathrm{ml})$. The ether layer was dried $\left(\mathrm{K}_{2} \mathrm{CO}_{3}\right)$ and evaporated to give $(d l)-\mathbf{1}$ as a yellow-colored oil. The oil was chromatographed on a column of $\mathrm{Al}_{2} \mathrm{O}_{3}$ (benzene) to give $(d l)-\mathbf{1}$ (49 mg) as needles, mp. $209-210^{\circ} \mathrm{C}$ (ether/MeOH). Single crystals suitable for $\mathrm{X}$-ray structure analysis were obtained by crystallization from a mixed solution of $\mathrm{CHCl}_{3}$ and $\mathrm{MeOH}$,
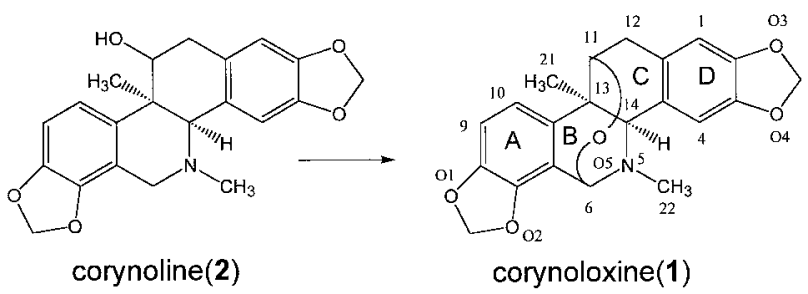

Fig. 1 Chemical formula of $\mathbf{1}$ and $\mathbf{2}$.

† To whom correspondence should be addressed.

E-mail: kamigami@kobepharma-u. ac.jp which afforded transparent needle crystals. The crystal and structure refinement data are summarized in Table 1 . The crystal structure of $(d l)-\mathbf{1}$ is shown in Fig. 2. The structure was determined to be $5 b, 6,7,12 b, 13,14$-hexahydro-5b,13-dimethyl6,14-epoxy-1,3-dioxolo[4,5-i][1,3]dioxolo[4,5]benzo[1,2$c$ phenanthridine and supports the chemically estimated structure. The crystal of $(d l)-\mathbf{1}$ contained two crystallographically independent molecules (molecule A, B). Characteristically, two molecules took essentially the same conformation, as is obvious in Fig. 2; only the bending degree of

Table 1 Crystal data and experimental data of $(d l)-\mathbf{1}$

CCDC deposition number: 701087

Chemical formula: $\mathrm{C}_{21} \mathrm{H}_{19} \mathrm{NO}_{5}$

Formula weight $=365.37$

$T=298 \mathrm{~K}$

Crystal system: orthorhombic

Space group: $\mathrm{Pbca}$

$a=20.375(3) \AA$

$b=41.499(3) \AA$

$c=8.139(3) \AA$

$V=6882(2) \AA^{3}$

$Z=16$

$D_{\text {(calc) }}=1.410 \mathrm{~g} / \mathrm{cm}^{-3}$

$\lambda\left(\mathrm{Cu} K_{\alpha}\right)=0.84 \mathrm{~mm}^{-1}$

$F\left(\begin{array}{lll}0 & 0 & 0\end{array}\right)=3072$

Radiation: $\mathrm{Cu} K_{\alpha}(\lambda=1.54180 \AA)$

No. of reflections collected $=6094$

No. of observed reflections $=3378$

$\theta$ range for data collection: 2.13 to $67.62^{\circ}$

Data/Restraints/Parameters $=3378 / 0 / 488$

Goodness-of-fit on $F^{2}=1.113$

$R$ indices $[I>2 \sigma(I)]: R 1=0.0695, w R 2=0.1712$

$R$ indices (all data): $R 1=0.1548, w R 2=0.2034$

$(\Delta / \sigma)_{\max }=0.004$

$(\Delta \rho)_{\max }=0.318$

$(\Delta \rho)_{\min }=-0.299$

Measurement: Rigaku AFC5R

Program system: WSC/AFC

Structure determination: SHELXS-97

Refinement: full matrix SHELXL-97 ${ }^{6}$ 

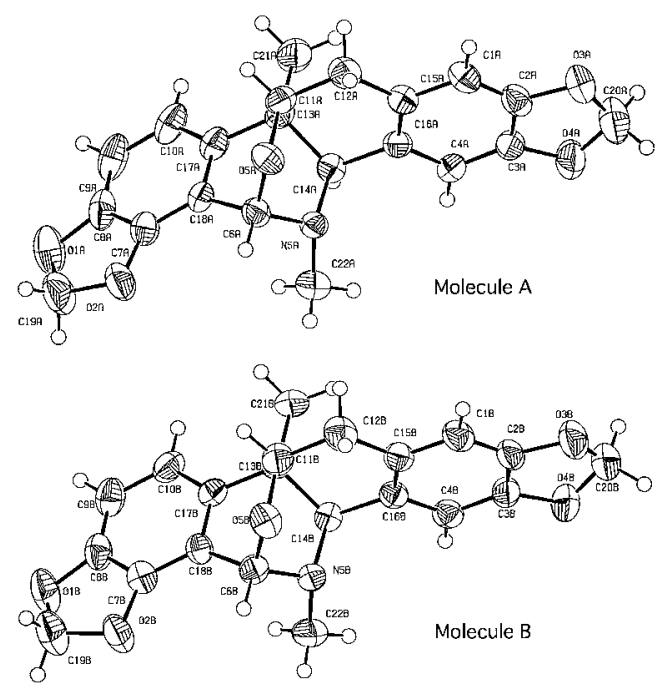

Fig. 2 ORTEP structure of two molecules of $(d l)$-corynoloxine (1), showing $50 \%$ probability ellipsoids.

the methylenedioxyl unit on the A or D ring was different between both molecules: torsion angle $\mathrm{C} 19-\mathrm{O} 1-\mathrm{C} 8-\mathrm{C} 7=2.2(7)^{\circ}$ for $\mathrm{A}$, and $14.2(6)^{\circ}$ for $\mathrm{B}$; $\mathrm{C} 8-\mathrm{O} 1-\mathrm{C} 19-\mathrm{O} 2=-3.2(7)^{\circ}$ for $\mathrm{A}$ and $-22.0(6)^{\circ}$ for $\mathrm{B}$. The cis conformation in the $\mathrm{B} / \mathrm{C}$ ring joint moiety of the hexahydrobenzo[c]phenanthridine skeleton is anticipated to lead to whole conformational flexibility. The B/C ring moiety of $(d l)-\mathbf{1}$ was shown to be of the anti-cis type. ${ }^{5}$ As for the C6-C11 ether linkage, the conformation adopted a twist- half-boat on the $\mathrm{B}$ ring and a twist-half-chair on the $\mathrm{C}$ ring. The direction of the $N$-methyl group was axial with respect to the B ring. This conformation agreed with that from the NMR spectroscopic method. The dihedral angle between two aromatic rings, $\mathrm{A}$ and $\mathrm{D}$, was $87.7(2)^{\circ}$ for both molecules. The ether bond cross-linking molecular center appears to be relatively less strained, because it forms a stable 6-member ring, and the bond lengths are within the usual value: O5-C6 = $1.418(6) \AA$ for $\mathrm{A}$ and $1.424(6) \AA$ for $\mathrm{B}$; O5-C11 = 1.443(6) $\AA$ for $\mathrm{A}$ and $1.441(6) \AA$ for $\mathrm{B}$. As the structural feature in the crystal $(d l)-\mathbf{1}$, no crystal solvents and no intermolecular hydrogen bonds were formed. The respective molecules are held by van der Waals forces among the neighboring molecules.

\section{References}

1. C. Tani and N. Takao, Yakugaku Zasshi, 1962, 82, 594.

2. N. Takao, Chem. Pharm. Bull., 1971, 19, 247.

3. M. Kamigauchi, Y. Noda, J. Nishijo, K. Iwasaki, K. Tobetto, Y. In, K. Tomoo, and T. Ishida, Bioorg. Med. Chem., 2005, $13,1867$.

4. H. Uemura, A. Takashima, K. Iwasaki, Y. Mukoyama, M. Kamigauchi, and K. Tobetto, Jpn. Kokai Tokkyo Koho, 1999, 13 pp. (Maruho K. K., Japan). CODEN: JKXXAFJP 11302174 A 19991102 Heisei.

5. N. Takao, M. Kamigauchi, K. Iwasa, N. Morita, and K. Kuriyama, Arc. Pharm., 1984, 317, 223.

6. Sheldrick GM (1997) SHELX97. Program for the Refinement of Crystal Structures. University of Gottingen, Germany. 